\title{
Building Mathematical Concepts Through Traditional Games to Develop Counting Skills for Early Childhood
}

\section{Widi Wulansari'1*, Linda Dwiyanti ${ }^{2}$}

\author{
1,2 Universitas Nusantara PGRI Kediri, Kediri, Indonesia
}

\section{ART ICLE INF O}

Article history:

Received September 23, 2021

Revised September 29, 2021

Accepted November 14, 2021

Available online November 25, 2021

Kata Kunci:

Konsep Matematika, Permainan

Tradisional, Berhitung

Keywords:

Math Concepts, Traditional Games, Counting

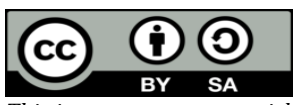

This is an open access article under the $\underline{C C}$ BY-SA license.

Copyright (C) 2021 by Author. Published by Universitas Pendidikan Ganesha.

\begin{abstract}
A B S T R A K
Dalam beberapa tahun terakhir, metode pembelajaran yang menyenangkan hampir menghilang dari ruang kelas sekolah. Selain itu ada pengurangan waktu bermain yang aktif dan kreatif sehingga membuat siswa merasa bosan. Penelitian ini bertujuan untuk membangun (C5) konsep matematika sederhana dengan permainan tradisional Dakon dan Ular Tangga dalam mengembangkan kemampuan berhitung pada anak berkemampuan berpikir tingkat tinggi dan rendah. Jenis penelitian yang digunakan merupakan penelitian eksperimen semu (quasi experiment) dengan desain faktorial $2 \times 2$. Subjek dalam penelitian ini adalah anak kelompok B sebanyak 60 anak. Teknik pengumpulan data yang digunakan dalam penelitian ini adalah tes, dan observasi. Instrumen yang digunakan adalah soal tes, dan lembar observasi dengan menggunakan 5 indikator pengukuran kemampuan berhitung. Analisis data menggunakan uji Two Way ANOVA. Hasil dalam penelitian ini yaitu membangun konsep matematika sederhana dengan permainan tradisional dakon untuk mengembangkan kemampuan berhitung pada anak berkemampuan berpikir tingkat tinggi memberikan hasil yang lebih baik daripada permainan tradisional ular tangga dengan nilai Selisih Mean sebesar 1,533 dan nilai Signifikansi 0, 0001. Membangun konsep matematika sederhana dengan permainan tradisional dakon untuk mengembangkan kemampuan berhitung pada anak berkemampuan berpikir tingkat rendah memberikan hasil yang lebih baik dibandingkan dengan permainan tradisional ular tangga dengan nilai Selisih Mean sebesar 2,867 dan nilai Signifikansi sebesar 0,0001. Dengan demikian dapat disimpulkan bahwa permainan tradisional Dakon sangat baik digunakan sebagai sarana untuk membangun konsep matematika sederhana khususnya kemampuan berhitung.
\end{abstract}

A B S T R A C T

In recent years, fun learning methods have almost disappeared from school classrooms. In addition, there is a reduction in active and creative playtime so that students feel bored. This study aims to build (C5) simple mathematical concepts with the traditional game Dakon and Snakes and Ladders in developing numeracy skills in children with high and low order thinking abilities. The type of research used is quasi-experimental research (quasi-experimental) with a $2 \times 2$ factorial design. The subjects in this study were 60 children in group B. The data collection techniques used in this study were tests and observations. The instrument used is a test question, and the observation sheet uses five indicators to measure the ability to count ata analysis using Two Way ANOVA test. This research aims to build a simple mathematical concept with traditional dakon games to develop numeracy skills in children with higher-order thinking skills, which gives better results than the traditional snake and ladder game with a Mean Difference value of 1.533 and a Significance value of 0.0001 . Building simple mathematical concepts with traditional dakon games to develop numeracy skills in children with low-level thinking abilities gave better results than the traditional snake and ladder game with a Mean Difference value of 2.867 and a Significance value of 0.0001 . Thus, it can be concluded that the traditional dakon game is very well used to build simple mathematical concepts, especially numeracy skills.

\section{INTRODUCTION}

Along with the passage of a person's life, mathematics becomes one part of life that will never be separated. We need to realize how essential and influential mathematics is in human life (Bicer et al., 2021; Nurlaily et al., 2019; Pratama \& Retnawati, 2018). From the results of surveys and research studies on the intelligence level of Indonesian children, the Program for International Student Assessment (PISA) exam system initiated by the Economic Co-operation and Development (OECD) explains the results of a survey conducted in 2015 where the Indonesian state's mathematics score was ranked 63rd. from 71 countries in the world (Nusantara et al., 2021; Umaroh \& Pujiastuti, 2020). So it is essential to introduce simple mathematical concepts starting at an early age. It is expected to be a person's initial foundation for obtaining basic mathematical concepts and subsequent or more complex mathematical concepts (Hadiyanti et al., 
2021; Kowiyah et al., 2019; Zandieh \& Rasmussen, 2010). The importance of introducing early mathematical concepts to early childhood dramatically affects a person's mindset and ability to analyze and solve a problem in his future life (Kowiyah et al., 2019; Yaniawati et al., 2019). Of course, it makes mathematics the basis for forming one's logical way of thinking. The introduction of mathematics in children from an early age can stimulate their ability to think logically, analytically, systematically, critically, and creatively in the ability to work together (Putri \& Suparno, 2020). The ability to think logically is also essential to support the development of learning science and mathematics. Therefore, one's ability to think logically must be formed from early childhood education.

Early childhood education, especially at the Kindergarten level, has programs to stimulate and develop children's potential in various aspects of development, such as cognitive, language, social, emotional, physical motor, religious, moral values, and art (Kandula et al., 2020; Kazu \& İș, 2018; Yates \& Twigg, 2017). Of the six aspects, cognitive is one of the essential aspects in early childhood development in the academic field (Peralbo-Uzquiano et al., 2020; Purpura \& Schmitt, 2019). Cognitive development is closely related to logical-mathematical and naturalist intelligence. Stimulating logical-mathematical intelligence can improve cognitive development, especially logical thinking, basic concepts, information processing, and problem-solving (Nur et al., 2018; Wati \& Wulansari, 2021). Simple mathematics is a part of cognitive development. Mathematics is an exact science that is the basis of other sciences so that Mathematics is interrelated with other sciences (Ambussaidi \& Yang, 2019; Baya'a et al., 2019). It would be better if interactions and activities closely related to mathematics were challenging, engaging, and become a necessity that is forced or because of compulsion (Kowiyah \& Mulyawati, 2018; Lin et al., 2020). In simple mathematics learning that is packaged in creative learning (playing) is a mathematics learning activity that is packaged through creative, stimulant activities and directly experienced by children (Hands-on Experiences) who can give positive feelings towards mathematics in the long term (Mirawati, 2017; Nurhayati \& Rasyid, 2019).

In fact, in Indonesia, the learning process for kindergarten children is still a problem in recent years (Aisyah et al., 2019; Risnawati \& Nuraeni, 2019). It is because learning patterns tend to be academically oriented and assume that the concepts that exist in children do not develop spontaneously but must be instilled and absorbed by children through adult treatment, where the teacher is the subject, and the child is the object of the learning process (Budianti, 2021; Jatmikowati et al., 2015). Currently, there are many elementary schools, exceptionally excellent elementary schools that use reading, writing, and counting ability as a test for screening new students entering elementary school (Asiah, 2018). It encourages educational institutions providing PAUD and parents to teach reading, writing actively, and counting abilities using learning in elementary schools that are not by the child's developmental stages (Asiah, 2018; Nurwahidah et al., 2021; Rekysika \& Haryanto, 2019). In recent years, fun learning methods have almost disappeared from school classrooms, and there is a reduction in active, creative playtime, both at home and outside the home. An educator needs to play a learning method to develop children's abilities, especially science and mathematics. Learning with the play method will encourage children so that they bring out and improve specific creativity, especially science and math skills (Manurung, 2021; Pitaloka et al., 2021).

In the learning process in early childhood, it should be carried out to provide basic concepts that have meaning for children, which can be done through playing or providing real experiences that will allow children to show activity and curiosity optimally (Nurani \& Mayangasri, 2017; Nurwahidah et al., 2021). It is because meaningful learning for early childhood is learning while playing. Play activities are the needs of early childhood that must be met. The game is a tool for children to channel their energy, satisfy their passions and fantasies, and intellectuals (Azis, 2019; Holis, 2016; Rahmatia et al., 2021). The world of children is playing, and children understand the world through the process of playing. Early childhood has characteristics that still like playing activities as the central part of learning (Suryaningsih \& Rimpiati, 2018; Trisniawati et al., 2018). Playing for children can provide joy and make the learning process more developed (Dwiyanti et al., 2018; Nurwahidah et al., 2021). The teaching and learning process for early childhood also emphasizes the principle of learning while playing and playing while learning. Such learning makes children's cognitive abilities emerge and develop through playing activities using game tools that contain educational elements or values (Aisyah et al., 2019; Dwiyanti et al., 2018; Muloke et al., 2017). The game itself is divided into two, namely Traditional Games and Modern Games.

Traditional games are games inherited by ancestors and need to be preserved because they contain local wisdom values, "good," "positive," "worth," and "desired" values. Traditional games for children in every region and community are shaped by local culture and environment (Puspitasari et al., 2021; Zayyadi et al., 2018). Each traditional game has its level of difficulty, so it is necessary to pay attention to the implementation of the game at its age stage, especially for early childhood. Parents and education practitioners must also understand that traditional games have many benefits for various aspects of children's development. Not only in the physical aspects of motor, but also in other aspects. One of these 
aspects is cognitive, especially in the introduction of simple mathematics, namely the ability to count. One of the traditional games suitable for early childhood in group B Kindergarten, especially in early arithmetic skills, is Congklak (Dakon) and Snakes and Ladders. The Dakon/Congklak game is a traditional board game that was quite popular in ancient times. Dakon can be played at leisure on the house's terrace or under a tree (Muslihatun et al., 2019; Susilawati et al., 2021). The learning and playing activities using congklak media are exciting and fun. By playing, children find new things, practice skills, and interest in learning mathematical concepts (Muslihatun et al., 2019; Putra \& Hasanah, 2018). At the same time, the Snake and Ladders game is a traditional game with a concept. Two or more children play this game by throwing dice consisting of several boxes with pictures (Afandi, 2015; Nawafilah \& Masruroh, 2020). A traditional game based on physical activity is essential to develop children's muscles. Since traditional games usually utilize handmade equipment, they can develop children's brain creativity (Eskasasnanda, 2017; Nugraha et al., 2018).

Modern games are games that are carried out using technological tools that have developed in the community and can be played by approximately two people and can even be done alone without a playmate so that with the development of the times and technology, the growth of children is growing so that the value of the child's character is getting lost (Novrialdy, 2019; Syafryadin et al., 2021). The results of field observations show that children, especially at an early age, are more fond of modern games than traditional games. However, it should be noted that traditional games have many benefits, especially in improving developmental aspects. Many parents find that quality games are the types of games made of expensive materials, and parents will feel proud if they can buy their children's games from abroad or imported toys (Lestariningrum, 2018; Munawaroh, 2017). Other than that, children are now more fond of modern games using gadgets, with various applications and games easily accessible to children through their gadgets (Rizal et al., 2020; Suryanda et al., 2019; Synnott, 2018). Not many parents are aware that gadgets negatively impact early childhood, but it is undeniable that wise use of gadgets also has a positive impact along with awareness and progress in an all-digital era (Rohayani, 2020; Widiyono, 2020). Some of the negative impacts when children are now happier with games using gadgets, including children being indifferent to the environment or people around them; Then all sensory and motor activity that children usually get when playing also decreases, and the brain, eyes, and fingers work more. In addition, the ability to recognize children's simple concepts is no longer obtained through experience. However, it is obtained from content presentations on devices and happiness. Those children used to get when playing with friends is now changing with the feelings of children being made pounding, with the ambition always to win and angry/depressed when losing while playing. Therefore, our research aims to build simple mathematical concepts with the traditional game of Dakon and Snakes and Ladders to develop numeracy skills in children with higher-order thinking abilities and lower-order thinking abilities.

\section{METHOD}

This study uses experimental research methods with research variables including two independent variables, namely the method of playing with traditional games (Snakes and Ladders, and Dakon) and simple mathematical concepts (high level and low level), and one dependent variable, namely the ability to count, with the following indicators: 1) Children are able to name numbers 1-20;2) the child is able to count numbers; 3 ) the child is able to add numbers correctly; 4 ) the child is able to reduce numbers correctly; 5) children are able to solve problems. The experimental design used is a $2 \times 2$ factorial design. In this design, there are two groups, each of which is randomly selected. The first group is the experimental group who learns through the method of playing with the traditional game of snakes and ladders. The second group is the experimental group who learns through the method of playing with traditional dakon games.

Sampling in this study was carried out by the method of stratified random sampling (Stratified Random Sampling). This is because this study takes samples based on a certain level, namely children who have high and low levels of simple mathematical concepts so that the sample used is group B kindergarten students from 3 schools in Kediri City as many as 60 children. The data collection technique used in this research is a matter of test (pretest and posttest), and observation. Test questions and observations were used to determine the child's numeracy skills using the traditional game method Snakes and Ladders and Dakon. The instruments used are test questions and observation sheets that have been consulted with experts and experienced kindergarten teachers. The ability to count in children is divided into 2, namely high thinking ability and low thinking ability by using the following formula. The grid instrument used in this study is presented in table 1 . 
Table 1. Research Instrument Grid

\begin{tabular}{|c|c|c|}
\hline No. & Indicator & Number \\
\hline 1 & Mention the numbers $1-20$ & 1,2 \\
\hline 2 & Counting numbers & 3,4 \\
\hline 3 & Add up numbers & 5,6 \\
\hline 4 & Reduce numbers & 7,8 \\
\hline 5 & Solve problems & 9,10 \\
\hline
\end{tabular}

Data analysis was conducted to find out and test the truth of the proposed hypothesis. This research is a quasi-experimental research with a $2 \times 2$ factorial design. Thus, the data analysis used the Two Way ANOVA test. This analysis is appropriate to compare the effects of giving different treatments, whether there are significant differences or not. In general, the primary analysis in factorial experimental designs is to compare the interaction effects between factors. If there is a difference in the interaction effect, then a simple effect analysis is carried out, and if there is no difference in the interaction effect, the primary effect analysis is carried out. For the hypothesis test to be carried out, the analysis prerequisite test must first be carried out, including the normality test and homogeneity test. The normality test is intended to determine whether the samples taken in this study come from a population that is normally distributed or not. The Kolmogorov-Smirnov test was carried out for the normality test, while the data homogeneity test was used for the Levene test.

\section{RESULT AND DISCUSSION}

\section{Result}

The children play dakon starting with a high five (determining who plays first) then the winning child takes the kecik and is placed one by one in the dakon hole. Through traditional dakon games, children can develop their numeracy skills. This is because, the concept of the Dakon game uses the concept of addition and subtraction when filling items one by one into the hole that is passed including our own master plan hole (left) except for the opponent's master plan hole. Other than that, traditional Dakon games also train fine motor manipulation skills, train concentration, educate children's sportsmanship, and also practice strategy skills (Zayyadi et al., 2018; Zayyadi \& Subaidi, 2017).
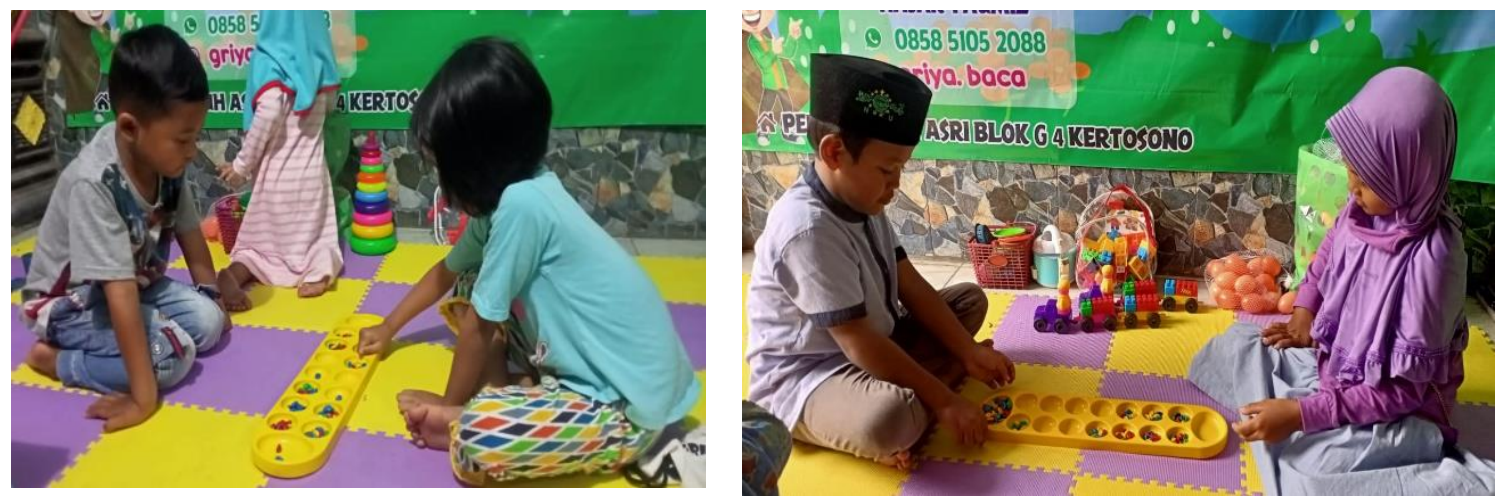

Picture 1. Traditional Games Dakon

The children started playing snakes and ladders with a high five (determining who played first). Then the child chooses the person to run (red/blue/yellow). After that the child shakes the dice and runs according to the number of dots on the dice. The game of snakes and ladders can improve the ability to count in children because in this game the child is assigned to count each step taken. This game also develops related mathematical abilities with communication, problem solving, understanding, and creative thinking (Atmoko et al., 2017; Nawafilah \& Masruroh, 2020; Sibuea \& Sinaga, 2018). 

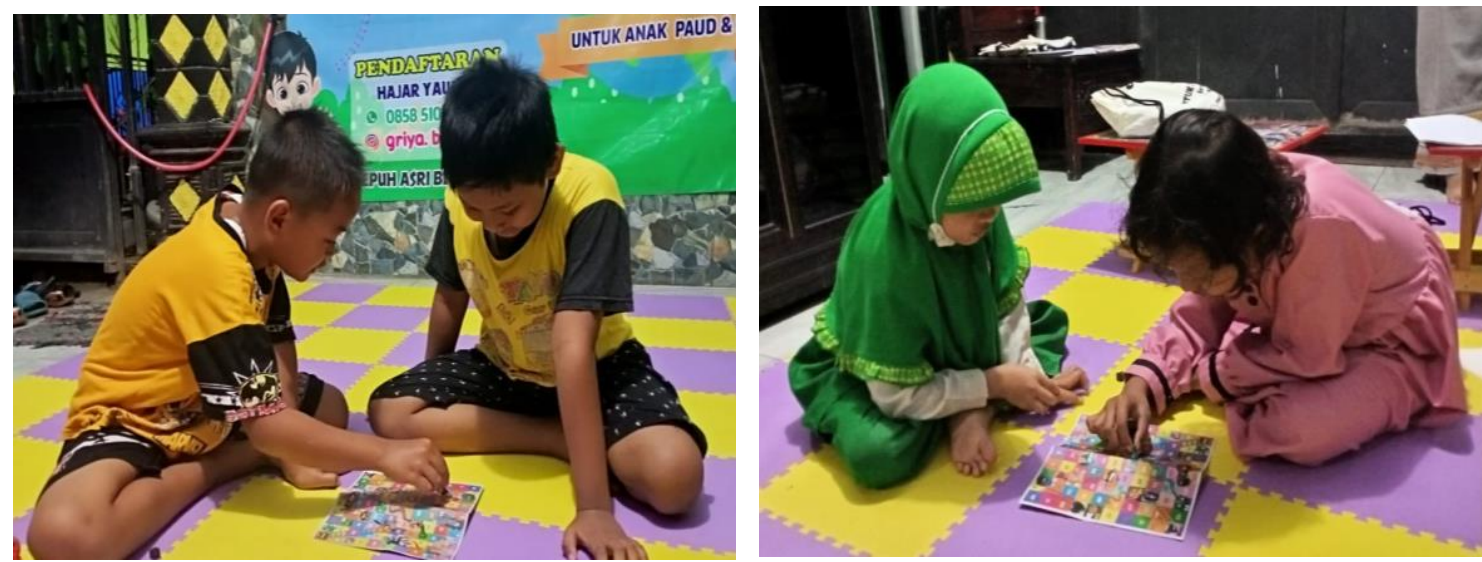

Picture 2. Traditional Games Snake and Ladders

Prior to the Two Way ANOVA test, assumptions were first tested which included normality and homogeneity tests with a sample of 60 children. The normality test is used to see whether the sample used in this study comes from a population that is normally distributed or not, while the homogeneity test is used to see whether the sample has the same variance or can be said to be homogeneous data. The results of the normality and homogeneity test with the help of the SPSS program show that the sig value for the normality test is 0.204 and the sig value for the homogeneity test is 0.803 . Based on the test result, it can be said that the samples taken in this study were normal and homogeneous. After the assumption test can be met, interaction analysis can be carried out. This analysis is used to see whether the interaction between traditional games and simple mathematical concepts has the same effect on early childhood numeracy skills. By using the $\mathrm{F}$ test for the interaction of traditional games and simple mathematical concepts, the value is 7.507 with a Sig value of 0.008 . Because the value of Sig is smaller than the predetermined alpha of 0.05 , the decision taken is to reject $\mathrm{H} 0$. So it can be concluded that there is an interaction between traditional games and thinking ability (TA). In other words, it can also be said that not all interactions between traditional games and simple mathematical concepts have the same effect on early childhood numeracy skills. Because there are interaction factors, the next analysis is simple effect analysis. This analysis is to answer more clearly "What types of traditional games are suitable for each level of thinking ability (TA); and conversely, what level of thinking ability (TA) is most suitable for each traditional game".

This analysis aims to answer the level of knowledge of what simple mathematical concepts are most appropriate for the traditional game of dakon and snakes and ladders. The test result shows the Sig value of 0.0001 . Because the value of Sig is smaller than the predetermined alpha of 0.05 , it can be concluded that the difference in the level of thinking ability with the traditional game of dakon and snakes and ladders gives different results. Furthermore, further tests were carried out to determine whether there was a significant difference between high and low levels of thinking ability. The building simple mathematical concepts with the traditional game of Dakon and Snakes and Ladders to develop numeracy skills in high thinking ability children better than low thinking ability children. So that means the application of traditional games, both Dakon (Game 1) and Snakes and Ladders (Game 2) is very appropriate to be given to children with high thinking ability. However, if it is seen from the results of the average difference, the traditional Dakon game (Game 1) is more appropriate to be given to children with knowledge of simple mathematical concepts at both high and low levels than the traditional Snake and Ladders game (Game 2).

This analysis aims to answer what types of traditional games are most appropriate for high-level and low-level simple math concepts. The test result shows the Sig value of 0.0001 . Because the Sig value is smaller than the predetermined alpha of 0.05 , it can be concluded that the different types of traditional games with high-level and low-level simple mathematical concepts give different results. Furthermore, further tests were carried out to determine the significant difference between the types of traditional games of Dakon and Anakes and Ladders. The building simple mathematical concepts with traditional Dakon games to develop numeracy skills in high and low thinking ability children is better than using the traditional Snakes and Ladders game. So that means the application of traditional games Dakon (Game 1) is very appropriate to be given to children with high thinking ability and low thinking ability.

\section{Discussion}

This study provides information that the method of playing through the traditional game of Dakon and Snakes and Ladders has a different effect on early childhood numeracy skills. The results of this study support previous research that traditional games can improve students' academic abilities by adjusting to 
their respective cultures and countries. The game congklak can be an alternative for teachers in increasing students' memory performance capacity, traditional games in Bengkulu, for example, the game "many people"; 'pack bananas'; "Sesimbunan," can provide benefits in stimulating children's growth and development (Iswinarti \& Suminar, 2019; Puspitasari et al., 2021).

Traditional games in this study have an impact on the level of knowledge of simple mathematical concepts. Children with a high level of knowledge of simple mathematical concepts have better numeracy skills when given the traditional game of Dakon than Snakes and Ladders. In contrast, for children with a low level of simple mathematical concepts, their numeracy skills will also be better if given the traditional game of Dakon than Snakes and Ladders. This traditional game is closely related to children's psychological abilities, especially cognitive development, and at the same time, can increase children's creativity (Damanik \& Sinaga, 2021; Pic et al., 2019). The research results are relevant that the dakon game as a traditional game is very effective in learning to count in introducing simple mathematical concepts. Several previous studies also support that the use of dakon games can facilitate understanding mathematical concepts (Asrial et al., 2020; Laily et al., 2019; Mulyani et al., 2020). In line with this, traditional games can improve problem-solving skills in children, stimulate language development, verbal skills, social skills, a good place for emotional expression for children, and increase children's learning motivation (Lestari \& Prima, 2017; Nataliya, 2015; Zayyadi et al., 2018). Children can rediscover the concept of adding numbers from their experience in playing the traditional game of dakon. The stages in a child's learning trajectory have an essential role in understanding the concept of number operations from the informal to the formal level (Nursyahidah et al., 2013; Prahmana et al., 2012).

Simple mathematical concepts with dakon games are efficient for students who have low-level thinking skills. It is evident in the study results where the dakon game has a reasonably high mean difference compared to the application of the snake and ladder game. The thing that becomes an obstacle in the snake and ladder game is that in the implementation of the snake and ladder game, it is only applied to specific materials, and students pay less attention to the rules of the snake and ladder game. These constraints can affect the increase in cognitive development in physiological maturity, experiences of children who have been through since childhood, and mental skills. However, on the other hand, based on the results of research that has been done, the use of the snake and ladder concept can improve the cognitive development of children who have learning difficulties. Research respondents showed that the concept of counting could be built well through the game of snakes and ladders. It can be seen when each player can reach the last stage in the game of snakes and ladders. At a glance, the snake and ladder game is a board game for children played by two or more people (Ibam, et al, 2018). Which consists of several elements, including game boards, dice, pawns, cards containing questions, bonus cards, surprise questions. and zonk cards (Ibam et al., 2018; Meriyati et al., 2019; Srinivasan, 2019).

The implication in learning with the application of games is that educators must be creative in using strategies and presenting learning media to catch the subject matter presented by the teacher quickly. Educators who will teach mathematics to early childhood should not be too textual, theoretical, and rigid during the learning process. Learning activities must be packed with play activities and be meaningful for children. Learning in early childhood education should use a quality preschool approach that can "invite children to experience mathematics as they play, describe and think about their world. Based on extensive research and training, teachers in early childhood education should plan activities that simultaneously involve cognitive, socio-emotional, and physical development and build on children's informal knowledge and experiences (Agusti et al., 2018; Hasibuan \& Jannah, 2018). Through creative games, children have more opportunities to enrich their movements. Various movements with motor-sensory, hands, feet, head, or another part of the body involving both big and small muscle will enable them to develop their physical motor ability fully. Play-based learning is currently getting more support, wherewith games, there are many valuable things that children get, namely strengthening many areas of development so that it must include games that can hone children's independence and get a grip. In the experience of playing, that still gets adult direction. In this case, the teacher's playfulness seems to predispose to specific creative actions, including those required in scientific and mathematical files.

\section{CONCLUSION}

BThe conclusion obtained from this study is that building simple mathematical concepts through traditional dakon games to develop numeracy skills in children with high and low-level thinking skills provides better and more effective results than the traditional snake and ladder game. 


\section{REFERENCES}

Afandi, R. (2015). Pengembangan Media Pembelajaran Permainan Ular Tangga Untuk Meningkatkan Motivasi Belajar Siswa dan Hasil Belajar IPS di Sekolah Dasar. INoP (Jurnal Inovasi Pembelajaran), 1(1). https://doi.org/10.22219/jinop.v1i1.2450.

Agusti, F. A., Zafirah, A., Anwar, F., \& Syafril, S. (2018). The Implantation Of Character Values Toward Students Through Congkak Game. Jurnal Penelitian Pendidikan (JPP), 35(2), 133-141. https://doi.org/10.15294/jpp.v35i2.13947.

Aisyah, E. N., Iriyanto, T., Astuti, W., \& Yafie, E. (2019). Peliharaan Sebagai Media Stimulasi Kemampuan Kognitif Anak Usia Dini. Jurnal Kajian Teknologi Pendidikan, 2(3), 174-180. https://doi.org/10.17977/um038v2i32019p174.

Alfulaila, N., Haryadi, Sudrajat, A., \& Nashrullah. (2019). The effectiveness of multicultural approach in writing achievement of Indonesian language among elementary school students. Cakrawala Pendidikan, 38(2), 366-376. https://doi.org/10.21831/cp.v38i2.23440.

Ambussaidi, I., \& Yang, Y.-F. (2019). The Impact of Mathematics Teacher Quality on Student Achievement in Oman and Taiwan. International Journal of Education and Learning, 1(2), 50-62. https://doi.org/10.31763/ijele.v1i2.39.

Asiah, N. (2018). Pembelajaran Calistung Pendidikan Anak Usia Dini Dan Ujian Masuk Calistung Sekolah Dasar Di Bandar Lampung. Terampil: Jurnal Pendidikan Dan Pembelajaran Dasar, 5(1), 19. https://doi.org/10.24042/terampil.v5i1.2746.

Asrial, A., Syahrial, S., Maison, M., Kurniawan, D. A., \& Perdana, R. (2020). A study of Traditional Games "Engklek" in Mathematics for Elementary School. Jurnal Ilmu Pendidikan, 26(1), 15-21. https://doi.org/10.17977/UM048V2611P15-21.

Atmoko, S. W., Cahyadi, F., \& Listyarini, I. (2017). Pengembangan Media Utama (Ular Tangga Matematika) dalam Pemecahan Masalah Matematika Materi Luas Keliling Bangun Datar Kelas III SD/MI. Al Ibtida: Jurnal Pendidikan Guru MI, 4(1), 119-128. https://doi.org/10.24235/al.ibtida.snj.v4i1.1476.

Azis, M. (2019). Analisis Kesulitan Belajar Membaca dan Menulis Permulaan PAUD Di Kelompok Bermain Fun Islamic School. Al-Athfaal: Jurnal Ilmiah Pendidikan Anak Usia Dini, 2(2). https://doi.org/10.24042/ajipaud.v2i2.5927.

Baya'a, N., Daher, W., \& Anabousy, A. (2019). The development of in-service mathematics teachers' integration of ICT in a community of practice: Teaching-in-context theory. International Journal of Emerging Technologies in Learning, 14(1), 125-139. https://doi.org/10.3991/ijet.v14i01.9134.

Bicer, A., Marquez, A., Colindres, K. V. M., Schanke, A. A., \& Castellon, L. B. (2021). Investigating creativitydirected tasks in middle school mathematics curricula. Thinking Skills and Creativity, 40. https://doi.org/10.1016/j.tsc.2021.100823.

Budianti, Y. (2021). Pengaruh Permainan Congklak dan Gatheng Terhadap Kecerdasan Logika Matematika Anak Usia Dini di RA Khiru Ummah. Jurnal Rudhah, 9(1), 93-108. https://doi.org/10.30829/raudhah.v9i1.945.

Damanik, R., \& Sinaga, W. (2021). The Values of Character in Traditional Games Simalungun Society. Budapest International Research and Critics Institute (BIRCI-Journal): Humanities and Social Sciences, 4(1), 1059-1069. https://doi.org/10.33258/birci.v4i1.1713.

Dwiyanti, L., Khan, R. I., \& Kurniawati, E. (2018). Development of Smart Adventure Games to Improve the Readiness of the Initial Ability of Reading, and Writing on Early Childhood. Jurnal Obsesi : Jurnal Pendidikan Anak Usia Dini, 2(2), 149. https://doi.org/10.31004/obsesi.v2i2.91.

Eskasasnanda, I. D. P. (2017). Causes and Effects of Online Video Game Playing among Junior-Senior High School Students in Malang East Java. KOMUNITAS: International Journal of Indonesian Society and Culture, 9(2), 191-202. https://doi.org/10.15294/komunitas.v9i2.9565.

Hadiyanti, N. F. D., Hobri, Prihandoko, A. C., Susanto, Murtikusuma, R. P., Khasanah, N., \& Maharani, P. (2021). Development of mathematics e-module with STEM-collaborative project based learning to improve mathematical literacy ability of vocational high school students. Journal of Physics: Conference Series, 1839(1). https://doi.org/10.1088/1742-6596/1839/1/012031.

Hasibuan, R., \& Jannah, M. (2018). Traditional Game "Engklek" and Young Children's Gross Motor Ability. 169(Icece 2017), 237-239. https://doi.org/10.2991/icece-17.2018.61.

Holis, A. (2016). Belajar Melalui Bermain untuk Pengembangan Kreativitas dan Kognitif Anak Usia Dini. Jurnal Pendidikan Universitas Garut, 9(1), 909-916. https://doi.org/10.1142/9789812773678_0145.

Ibam, E., Adekunle, T., \& Agbonifo, O. (2018). A Moral Education Learning System based on the Snakes and Ladders Game. EAI Endorsed Transactions on E-Learning, 5(17), 1-9. https://doi.org/10.4108/eai.25-9-2018.155641.

Iswinarti, \& Suminar, D. R. (2019). Improving children's problem-solving skills through javanese traditional 
games. Cakrawala Pendidikan, 38(3), 578-589. https://doi.org/10.21831/cp.v38i3.25331.

Jatmikowati, T. E., Angin, R., \& Ernawati, E. (2015). Model Dan Materi Pendidikan Seks Anak Usia Dini Perspektif Gender Untuk Menghindarkan Sexual Abuse. Cakrawala Pendidikan, 3(3). https://doi.org/10.21831/cp.v3i3.7407.

Kandula, T., Susanna, Carey, K. A., \& Cindy. (2020). Peripheral nerve maturation and excitability properties from early childhood: Comparison of motor and sensory nerves. Clinical Neurophysiology, 131(10). https://doi.org/10.1016/j.clinph.2020.06.035.

Kazu, İ. Y., \& İş, A. (2018). An Investigation About Actualization Levels of Learning Outcomes in Early Childhood Curriculum. Journal of Education and Training Studies, 6(3), 66. https://doi.org/10.11114/jets.v6i3.2928.

Kowiyah, K., Mulyawati, I., \& Umam, K. (2019). Conceptual Understanding and Mathematical Representation Analysis of Realistic Mathematics Education Based on Personality Types. Al-Jabar: Jurnal Pendidikan Matematika, 10(2), 201-210. https://doi.org/10.24042/ajpm.v10i2.4605.

Kowiyah, \& Mulyawati, I. (2018). An analysis of primary school students' representational ability in mathematics based on gender perspective. Journal of Physics: Conference Series, 948(1). https://doi.org/10.1088/1742-6596/948/1/012016.

Laily, A., Jalal, F., \& Karnadi, K. (2019). Peningkatan Kemampuan Konsep Matematika Awal Anak Usia 4-5 Tahun melalui Media Papan Semat. Jurnal Obsesi, 3(2). https://doi.org/10.31004/obsesi.v3i2.214.

Lestari, P. I., \& Prima, E. (2017). The Implementation of Traditional Games to Improve the Social Emotional Early Childhood. Journal of Educational Science and Technology (EST), 3(3), 178-184. https://doi.org/10.26858/est.v3i3.4212.

Lestariningrum, A. (2018). the Effects of Traditional Game 'Congklak' and Self-Confidence Towards Logical Mathematical Intelligence of 5-6 Years Children. Jurnal INDRIA (Jurnal Ilmiah Pendidikan Prasekolah Dan Sekolah Awal), 3(1), 13-22. https://doi.org/10.24269/jin.v3n1.2018.pp13-22.

Lin, S., Zhou, Y., \& Wijaya, T. T. (2020). Using hawgent dynamic mathematics software in teaching arithmetic operation. International Journal of Education and Learning, 2(1), 25-31. https://doi.org/10.31763/ijele.v2i1.97.

Manurung, A. K. R. dkk. (2021). Permainan Outdoor dalam Membentuk Kemampuan Ketahanmalangan pada Anak Usia Dini. Jurnal Pendidikan Anak Usia Dini, 5(2), 1807-1814. https://doi.org/10.31004/obsesi.v5i2.1030.

Meriyati, M., Latifah, S., Hidayah, N., Shawmi, A. N., Amrullah, M. A., \& Fitriana, N. S. (2019). Snake and Ladder Game Integrated with Asmaul-husna: Development of Learning Media. Journal of Physics: Conference Series, 1155(1). https://doi.org/10.1088/1742-6596/1155/1/012024.

Mirawati. (2017). Matematika Kreatif: Pembelajaran Matematika bagi Anak Usia Dini Melalui Kegiatan yang Menyenangkan dan Bermakna. PEDAGOGI: Jurnal Anak Usia Dini Dan Pendidikan Anak Usia Dini, 3(3), 1-8. https://doi.org/10.30651/pedagogi.v3i3a.1027.

Muloke, I., Ismanto, A., \& Bataha, Y. (2017). Pengaruh Alat Permainan Edukatif (Puzzle) Terhadap Perkembangan Kognitif Anak Usia 5-6 Tahun Di Desa Linawan Kecamatan Pinolosian Kabupaten Bolaang Mongondow Selatan. Jurnal Keperawatan UNSRAT, 5(1), 111977. https://doi.org/10.35790/jkp.v5i1.14718.

Mulyani, D., Cahyati, N., \& Rahma, A. (2020). Pengembangan Media Permainan Dakon untuk Meningkatkan Kemampuan Berhitung Anak. Al-Athfaal: Jurnal Ilmiah Pendidikan Anak Usia Dini, 3(2), 161-172. https://doi.org/10.31004/obsesi.v4i2.428.

Munawaroh, H. (2017). Pengembangan Model Pembelajaran dengan Permainan Tradisional Engklek Sebagai Sarana Stimulasi Perkembangan Anak Usia Dini. Jurnal Obsesi : Jurnal Pendidikan Anak Usia Dini, 1(2), 86-96. https://doi.org/10.31004/obsesi.v1i2.19.

Muslihatun, A., Cahyaningtyas, L., Khaimmudin, R. N. L. H., Fijatullah, R. N., Nisa', E. U., \& Sari, C. K. (2019). Pemanfaatan Permainan Tradisional untuk Media Pembelajaran: Congklak Bilangan sebagai Inovasi Pembelajaran Matematika Sekolah Dasar. Transformasi: Jurnal Pengabdian Masyarakat, 15(1), 14-22. https://doi.org/10.20414/transformasi.v15i1.915.

Nataliya, P. (2015). Efektivitas Penggunaan Media Pembelajaran Permainan Tradisional Congklak Untuk Meningkatkan Kemampuan Berhitung Pada Siswa Sekolah Dasar. Jurnal Ilmiah Psikologi Terapan, 3(2), 343-358. https://doi.org/10.22219/jipt.v3i2.3536.

Nawafilah, N. Q., \& Masruroh, M. (2020). Pengembangan Alat Permainan Edukatif Ular Tangga Matematika untuk Meningkatkan Kemampuan Berhitung Anak Kelas III SDN Guminingrejo Tikung Lamongan. Jurnal Abdimas Berdaya: Jurnal Pembelajaran, Pemberdayaan Dan Pengabdian Masyarakat, 3(1), 37-46. https://doi.org/10.30736/jab.v3i01.42.

Novrialdy, E. (2019). Kecanduan Game Online pada Remaja: Dampak dan Pencegahannya. Buletin Psikologi, 27(2), 148-158. https://doi.org/10.22146/buletinpsikologi.47402. 
Nugraha, Y. A., Handoyo, E., \& Sulistyorini, S. (2018). Traditional Game on The Social Skill of Students in The Social Science Learning of Elementary School. Journal of Primary Education, 7(2), 220-227. https://doi.org/10.15294/jpe.v7i2.23475.

Nur, I. R. D., Herman, T., \& Mariyana, R. (2018). Logical-Mathematics Intellegence in Early Childhood Students. International Journal of Social Science and Humanity, 8(4), 105-109. https://doi.org/10.18178/ijssh.2018.V8.944.

Nurani, Y., \& Mayangasri, T. (2017). Pengembangan Model Kegiatan Sentra Bermain Dalam Mengembangkan Kreativitas Anak Usia Dini. Jurnal Pendidikan Usia Dini, 11(2). https://doi.org/10.21009/JPUD.112.15.

Nurhayati, F., \& Rasyid, H. (2019). Implementation of Outdoor Games to Improve 4-5 Year Old Childrens Number Sense. Jurnal Obsesi: Jurnal Pendidikan Anak Usia Dini, 3(1), 10. https://doi.org/10.31004/obsesi.v3i1.133.

Nurlaily, V. A., Soegiyanto, H., \& Usodo, B. (2019). Elementary school teacher's obstacles in the implementation of problem-based learning model in mathematics learning. Journal on Mathematics Education, 10(2), 229-238. https://doi.org/10.22342/jme.10.2.5386.229-238.

Nursyahidah, F., Putri, R. I. I., \& Somakim. (2013). Supporting First Grade Students' Understanding of Addition Up to 20 Using Traditional Game. Journal on Mathematics Education, 4(2), 212-223. https: //doi.org/10.22342/jme.4.2.557.212-223.

Nurwahidah, Maryati, S., Nurlaela, W., \& Cahyana. (2021). Permainan Tradisional Sebagai Sarana Mengembangkan Kemampuan Fisik Motorik Anak Usia Dini. PAUD Lectura: Jurnal Pendidikan Anak Usia Dini, 4(02), 49-61. https://doi.org/10.31849/paud-lectura.v4i02.6422.

Nusantara, D. S., Zulkardi, \& Putri, R. I. I. (2021). Designing pisa-like mathematics task using a COVID-19 context (Pisacomat). Journal on Mathematics Education, 12(2), 349-364. https: //doi.org/10.22342/JME.12.2.13181.349-364.

Peralbo-Uzquiano, M., Fernández-Abella, R., Durán-Bouza, M., José-Manuel Cotos-YáñezBrenlla-Blanco, J.-C., \& Brenlla-Blanco, J.-C. (2020). Evaluation of the effects of a virtual intervention programme on cognitive flexibility, inhibitory control and basic math skills in childhood education. Computers \& Education, 159. https://doi.org/10.1016/j.compedu.2020.104006.

Pic, M., Lavega-Burgués, P., \& March-Llanes, J. (2019). Motor behaviour through traditional games. Educational Studies, 45(6), 742-755. https://doi.org/10.1080/03055698.2018.1516630.

Pitaloka, D. L., Dimyati, D., \& Edi, P. (2021). Peran Guru dalam Menanamkan Nilai Toleransi pada Anak Usia Dini di Indonesia. Jurnal Obsesi: Jurnal Pendidikan Anak Usia Dini, 5(2), 1696-1705. https://doi.org/10.31004/obsesi.v5i2.972.

Prahmana, R. C. I., Zulkardi, \& Hartono, Y. (2012). Learning Multiplication Using Indonesian Traditional game in Third Grade. Journal on Mathematics Education, 3(2), 1-16. https: //doi.org/10.22342/jme.3.2.1931.115-132.

Pratama, G. S., \& Retnawati, H. (2018). Urgency of Higher Order Thinking Skills (HOTS) Content Analysis in Mathematics Textbook. Journal of Physics: Conference Series, 1097(1). https://doi.org/10.1088/1742-6596/1097/1/012147.

Purpura, D. J., \& Schmitt, S. A. (2019). Cross-domain development of early academic and cognitive skills. Early Childhood Research Quarterly, 46,1-4. https://doi.org/10.1016/j.ecresq.2018.10.009.

Puspitasari, I. P., Rachmawati, Y., Romadona, N. F., \& Purnamasari, I. (2021). Bengkulu's Traditional Games for Young Children. Proceedings of the 5th International Conference on Early Childhood Education (ICECE 2020), 538(Icece 2020), 27-32. https://doi.org/10.2991/assehr.k.210322.007.

Putra, A., \& Hasanah, V. R. (2018). Traditional Game To Develop Character Values in Nonformal Educational Institution. IJAEDU- International E-Journal of Advances in Education, IV(10), 86-92. https://doi.org/10.18768/ijaedu.415411.

Putri, A. A., \& Suparno. (2020). Recognize Geometry Shapes through Computer Learning in Early Math Skills. JPUD - Jurnal Pendidikan Usia Dini, 14(1), 50-64. https://doi.org/10.21009/jpud.141.04.

Rahmatia, R., Pajarianto, H., Kadir, A., Ulpi, W., \& Yusuf, M. (2021). Pengembangan Model Bermain Konstruktif dengan Media Balok untuk Meningkatkan Visual-Spasial Anak. Jurnal Obsesi : Jurnal Pendidikan Anak Usia Dini, 6(1). https://doi.org/10.31004/obsesi.v6i1.1185.

Rekysika, N. S., \& Haryanto, H. (2019). Media Pembelajaran Ular Tangga Bilangan Untuk Meningkatkan Kemampuan Kognitif Anak Usia 5-6 Tahun. Cakrawala Dini: Jurnal Pendidikan Anak Usia Dini, 10(1), 56-61. https://doi.org/10.17509/cd.v10i1.16000.

Risnawati, A., \& Nuraeni, L. (2019). Meningkatkan Kemampuan Berbahasa Sunda Anak Usia Dini Melalui Kegiatan Rebo Nyunda Di Pendidikan Anak Usia Dini. CERIA (Cerdas Energik Responsif Inovatif Adaptif), 2(5). https://doi.org/10.22460/ceria.v2i5.p243-250.

Rizal, R., Rusdiana, D., Setiawan, W., \& Siahaan, P. (2020). Students perception of learning management 
system supported smartphone: Satisfaction analysis in online physics learning. Jurnal Pendidikan IPA Indonesia, 9(4), 600-610. https://doi.org/10.15294/jpii.v9i4.25363.

Rohayani, F. (2020). Menjawab Problematika yang Dihadapi Anak Usia Dini di Masa Pandemi CoVID-19 (Answering the Problems Facing Early Childhood During the COVID-19 Pandemic). Qawwam: Journal For Gender Mainstreaming, 14(1), 29-50. https://doi.org/10.20414/Qawwam.v14i1.2310.

Sibuea, M. F. L., \& Sinaga, H. D. E. (2018). Peningkatan Kemampuan Matematika Siswa Sekolah Dasar Melalui Media Pembelajaran Ular Tangga Aljabar. Jurnal Matematics Paedagogic, 3(1), 25-30. https://doi.org/10.36294/jmp.v3i1.304.

Srinivasan, K. (2019). Snake and Ladder Games in Cognition Development on Students with Learning Difficulties. Indian Journal of Dental Advancements, 10(4), 160-170. https://doi.org/10.5866/2018.10.10160.

Suryanda, A., Sartono, N., \& Sa'diyah, H. (2019). Developing smartphone-based laboratory manual as a learning media. Journal of Physics: Conference Series, 402. https://doi.org/10.1088/17426596/1402/7/077077.

Suryaningsih, N. M. A., \& Rimpiati, N. L. (2018). Implementation of Game-Based Thematic Science Approach in Developing Early Childhood Cognitive Capabilities. Jurnal Obsesi : Jurnal Pendidikan Anak Usia Dini, 2(2), 194-201. https://doi.org/10.31004/obsesi.v2i2.90.

Susilawati, E., Puspitasari, D., Kusumadewi, F., \& Nuryanih, L. (2021). Modifikasi Permainan Tradisional Congklak Terhadap Kemampuan Berhitung Untuk Meningkatkan Perkembangan Kognitif Pada Anak Usia Dini Tahun 2020. Jurnal Mutiara Ners, 4(1), 24-30. https://doi.org/10.51544/jmn.v4i1.1297.

Syafryadin, S., Boulahnane, S., \& Budaya, D. A. N. (2021). Immersing Japanese Students Into English Language Learning: Songs, Games And Cultures. Cakrawala Pendidikan, 40(3), 554-563. https://doi.org/10.21831/cp.v40i3.37153.

Synnott, K. C. (2018). Smartphones in the Classroom: Students' Misperceptions. Journal of Higeher Education Management, 33(1), 119-135. https://doi.org/10.2139/ssrn.3038013.

Trisniawati, Rahayu, A., \& Rhosyida, N. (2018). Implementasi Pembelajaran Origamasains Matematika Dan Sains Sejak Dini the Implementation of Origamasains Learning To Emerge Fondness To Mathematics and Science. Jurnal Ilmiah VISI PGTK PAUD Dan Dikmas, 13(2), 91-99. https://doi.org/10.21009/JIV.1302.3.

Umaroh, U., \& Pujiastuti, H. (2020). Analisis Kemampuan Representasi Matematis Siswa dalam Mengerjakan Soal PISA Ditinjau dari Perbedaan Gender. Jurnal Pendidikan Matematika Raflesia, 05(02), 40-53. https://doi.org/10.33449/jpmr.v5i2.11408.

Wati, E. K., \& Wulansari, W. (2021). LOP Game Development to Improve Early Childhood MathematicalLogic Learning Ability. JPI (Jurnal Pendidikan Indonesia), 10(1), 68-78. https://doi.org/10.23887/jpi-undiksha.v10i1.28406.

Widiyono, A. (2020). Efektifitas Perkuliahan Daring (Online) pada Mahasiswa PGSD di Saat Pandemi Covid 19. Jurnal Pendidikan, 8(2), 169-177. https://doi.org/10.36232/pendidikan.v8i2.458.

Yaniawati, R. P., Indrawan, R., \& Setiawan, G. (2019). Core Model on Improving Mathematical Communication and Connection, Analysis of Students' Mathematical Disposition. International Journal of Instruction, 12(4), 639-654. https://doi.org/10.29333/iji.2019.12441a.

Yates, E., \& Twigg, E. (2017). Developing creativity in early childhood studies students. Thinking Skills and Creativity, 23. https://doi.org/10.1016/j.tsc.2016.11.001.

Zandieh, M., \& Rasmussen, C. (2010). Defining as a mathematical activity: A framework for characterizing progress from informal to more formal ways of reasoning. The Journal of Mathematical Behavior, 29(2). https://doi.org/10.1016/j.jmathb.2010.01.001.

Zayyadi, M., Hasanah, S. I., \& Surahmi, E. (2018). Ethnomatematics Exploration in Traditional Games as a Form of Student' Social Interaction. JIPM (Jurnal Ilmiah Pendidikan Matematika), 6(2), 125-132. https://doi.org/10.25273/jipm.v6i2.1826.

Zayyadi, M., \& Subaidi, A. (2017). Berpikir Kritis Mahasiswa dalam Memecahkan Masalah Aljabar. Paedagoria: Jurnal Kajian, Penelitian, Dan Pengembangan Kependidikan, 8(2), 10-15. https://doi.org/https://doi.org/10.31764/paedagoria.v8i2.61. 